\title{
PARAÁLLAMI FORMÁK A MAI MAGYAR KÖZIGAZGATÁSBAN
}

\author{
(Parastate Models in the Present Hungarian Administration)
}

\section{BALÁZS ISTVÁN}

Közel egy évtizede - a közigazgatási rendszerváltáshoz kötőđően - került sor a klasszikus polgári közigazgatást kiegészító alternatív közigazgatás alkalmazásának áttekintésére (Balázs 1990). A magyar közjogi irodalomban ezt követően időszakonként vizsgálat alá került az is (Balázs 1994), hogy az új típusú és folyamatosan fejlődő magyar közigazgatásban milyen teret nyertek az alternativ kőzigazgatást megerősítő közvetett közigazgatási formák, hol és miképpen alakultak ki autonóm struktúrák? Jelen írásomban - a közigazgatás fejlesztésében eltőltőtt évtizednyi tapasztalataim alapján - kísérletet teszek arra, hogy a teljesség igénye nélkül, és vállalva a szubjektivitásból eredỏ esetleges hibákat, egyenleget vonjak a hazai helyzetet illetően.

\section{A közvetett közigazgatás és az autonóm struktúrák, mint az alternativ közigazgatás megjelenési formái}

Elméleti megközelítést alkalmazva paraállami közigazgatási formákról akkor beszélünk, amikor közigazgatási tevékenységet nem közigazgatási szervek végeznek. Ezen belưl azonban tágabb és szükebb megközelítés egyaránt lehetséges és szükséges.

A közvetett közigazgatás fogalma magában foglal minden olyan közigazgatási tevékenységet, amit nem - az adott jogrendszerben erre a célra létrehozott - közigazgatási szervek végeznek. Az ilyen felhatalmazás lehet általános törvény, mint pl. Magyarországon, vagy eseti az egyes ágazati jogszabályokban. A kőzvetett közigazgatást végző szervek lehetnek jogi személyek, és kivételesen erre feljogosított lehet magánszemély is, mint természetes személy. Ez utóbbi nem azonos azzal, amikor jogszabály nevesít választott közigazgatási tisztségviselöt, vagy önálló hatáskörrel köztisztviselöt (pl. jegyző, anyakönyvvezető stb.).

Közvetett kőzigazgatási tevékenységet leggyakrabban egyesületek, alapítványok, kamarák és más köztestületek illetve gazdasági társaságok végezhetnek. A közjog és a magánjog elkülönülését követö jogrendszerekben az említett jogi személyeknek van közjogi változata, igy pl. köztestület, közalapítvány, közhasznú vállalat vagy közintézet, kőzigazgatási tevékenységet csak e típusú szervek végezhetnek.

Más, az egységes jogrendszer alapján álló országokban a magánjogi jogi személyek közhasznú tevékenységének elismerésére mód van. A felsorolt szervek közös jellemzője azonban az, hogy azok nem állami szervek illetve nem közigazgatási onkormányzatok. 
Van azonban olyan eset is, amikor közigazgatási tevékenységet bár állami szervek végeznek, de azok nem a végrehajtó hatalmi ágba tartozó közigazgatási szervek. Az állami szervek rendszerében az alapvető államhatalmi ágaknak megfelelö kategórizálást végezhetünk, és felfogás kérdése, hogy a klasszikus triász mellett még milyen más, önálló hatalmi ág jellegủ szervet ismerünk el (pl. közigazgatási önkormányzatok).

Vannak azonban olyan állami szervek, amelyek az alapvetö államhatalmi ágak mindegyikének megfelelő tevékenységet végeznek, anélkül, hogy egyértelmüen bármelyik hatalmi ágba besorolhatóak lennének. Ezeket a szakirodalom összefoglaló névvel „autonóm struktúráknak” nevezi. Az autonóm struktúrák így kvázi bírósági, kvázi szabályozó és kvázi közigazgatási tevékenységet végeznek. Közvetett közigazgatást tehát autonóm struktúrák is végezhetnek, de nem minden közvetett közigazgatást végző szerv autonóm struktúra.

A közvetett közigazgatás vagy paraetatikus közigazgatás a közigazgatási szakirodalomban régóta ismert fogalom és jelenség', az autonóm struktúrák problémaköre azonban viszonylag új, a 20. század utolsó negyedének tipikus jelensége (ColliardTimsit 1988). Az autonóm struktúrák kialakulását egyesek a klasszikus államhatalmi ágak müködési problémáinak tulajdonítják, míg mások az állami szerepkörök megváltozását tükröző progresszív változásnak tételezik. Tény azonban az, hogy a közvetett közigazgatás, vagy annak egyik megjelenési formáját jelentő autonóm struktúrák a klasszikus közigazgatást kiegészítő, de azt sehol sem helyettesítő alternativák.

\section{A magyar közigazgatás jellege}

A magyar közigazgatás az 1980-as évek végén a rendszerváltáshoz kötött gyökeres átalakuláson esett át. Az azóta eltelt közel egy évtized alatt kialakultak a plurális polgári jogállamnak megfelelő közigazgatás alapelemei, az egymástól funkcionálisan és szervezetileg elkülönülő államigazgatás és az önkormányzati közigazgatás együtt jelentik a közigazgatást.

$\mathrm{Az}$ átalakulás folyamatában azonban - történelmi okokból - a tanácsrendszerü helyi igazgatást felváltó önkormányzati közigazgatás határozta meg a közigazgatás más elemeinek mozgásterét is. A helyi önkormányzatok gyors kialakitása és müködtetése a demokratikus átalakulás alapvetỏ feltétele volt. A modellül szolgáló "helyi önkormányzatok európai chartaja" ${ }^{2}$ magában foglalja az önkormányzati típusú, helyi közigazgatás európai értékeit és mindazon perspektivikus célkitúzéseket, melyeket az egyes országok konkrét rendszerei megvalósíthatnak.

A magyar jogi szabályozás a hatályos önkormányzati törvényben az önkormányzati charta szinte minden rendelkezését átvette (a nem kötelezöket is), ennélfogva a jogi szabályozás szintjén a világ egyik legliberálisabb önkormányzati rendszerét intézményesítette.

A bevezetés óta eltelt időszak bizonyította azt, hogy ez a rendszer beváltotta a hozzáfüzött reményeket még akkor is, ha a müködtetéséhez szükséges, föként pénz- 
ugyi feltételek nem mindig és mindenütt adottak. A közigazgatás két elemének, az államigazgatásnak és az önkormányzati közigazgatásnak egymáshoz való viszonyulása - más tradicionális demokráciákhoz képest - laza. A Kormány által gyakorolt törvényességi ellenörzés lényegében nem ad módot az önkormányzatok életébe történő aktív beavatkozásra, a pénzügyi-gazdasági ellenörzés pedig a parlamenti szerv kizárólagos hatásköre. A szubszidiaritás elvének helyenként történö túlhangsúlyozása problémát okoz a települési és a területi szintủ önkormányzatok viszonyában.

A magyar önkormányzati rendszer a széles felelősségü típusokhoz tartozik, a saját kötelezö és önként felvállalható feladat- és hatáskörök mellett egy önkormányzati köztisztviselö, a jegyző az általános elsőfokú államigazgatási hatóság is.

Mindezek következtében az önkormányzatok nem csupán a lakossági közszolgáltatások fỏ szervezöi, de rajtuk van az államigazgatás közhatalmi tevékenységének fỏ súlya is.

A széles felelősségkörhöz ezen túlmenően egy - a nyugat-európai önkormányzati fejlődéshez képest szokatlan -, a magánszférával vetélkedő tulajdonosi pozíció is társul.

A szocialista állami tulajdon lebontásához kötött önkormányzati tulajdon kialakulása a térség rendszerváltó országai közül is kiemeli Magyarországot e speciális megoldással. A liberális, széles felelősségkörủ és erös tulajdonosi pozícióban lévő önkormányzati közigazgatási rendszer mellett az államigazgatás viszonylag gyenge. Bár az elmúlt években az államigazgatás is számos változáson esett át, mủködésében azonban jóval tradicionálisabb, a korszerü közigazgatás fejlettebb államokban alkalmazott megoldásai kevésbé érintették.

Az alapvetó jellegzetességek áttekintése azért szükséges, mert ez az az alap, amelyen a paraetatikus közigazgatás érvényesülhet. Meglátásom szerint az elemzés alapján egyértelmüen kitünik az, hogy a magyar közigazgatásban az államigazgatás az, ahol az alternatív igazgatási formák megjelenésükkel oldhatják a tradicionális merevséget, míg az önkormányzati rendszerünk önmagában is elég atipikus elemet tartalmaz, ezért helyi szinten a közvetett közigazgatásra az önkormányzati közhatalmi feladatok tekintetében kevésbé van szükség.

\section{Paraállami formák a magyar közigazgatásban}

\section{Jogi keretek}

A magyar közigazgatásban a közvetett közigazgatásnak törvényi alapjai és garanciái vannak. Az államigazgatási eljárás általános szabályáról szóló 1957. évi IV. tv. 3. § (2) bek. szerint „Törvény, törvényerejủ rendelet vagy kormányrendelet közigazgatási szerven kívưl államigazgatási ủgy intézésére más szervet is feljogosíthat." $\mathrm{A}$ (3) bekezdés pedig rögzíti azt, hogy mit kell érteni államigazgatási ügy alatt. $\mathrm{Az}$ említett rendelkezés azonban csak az államigazgatási szervek által végzett államigazgatási ügyekre terjed ki. Az önkormányzati közigazgatási szervek önkormányzati ủgyeire más rendelkezést kell alkalmazni. 
Az Önkormányzati törvény (Ötv.) 9. §-a alapján látszólag úgy tủnik, mintha az önkormányzati feladatokat csak a képviselö-testulet szervei láthatnák el, így fel sem merülhet más lehetöség. Csakhogy a 9. §. (4) bek. éppen azt rögzíti, hogy a települési önkormányzatok fö feladatát képezö közszolgáltatások megvalósítására az önkormányzatok intézményt, vállalatot és más szervet hozhatnak létre, sőt a gyakorlatban ez a fö megoldási forma. A vázolt megoldás azonban nem tartozik sem a közvetett közigazgatás, sem pedig az autonóm struktúrák körébe.

A közvetett közigazgatás esetében ugyanis a nem közigazgatási szerv által ellátott közigazgatási tevékenységet nem a feladat-és hatáskör eredeti címzettje adja to$v a ́ b b$, delegálja, hanem a jogalkotó. Az önkormányzatok esetében első látásra, erre eleve nincs mód az Alkotmány szerint. Csakhogy az Ötv. 1. §-a deklarálja azt, hogy a helyi önkormányzatok a helyi érdekủ közügyekben önállóan járnak el. A helyi közügy fogalmát a (2) bekezdés határozza meg. A konkrét feladat- és hatáskörtelepítési kérdéseket taglaló 6 . § (2) bekezdése pedig azt mondja, hogy „Törvény kivételesen utalhat helyi közügyet más szerv feladat- és hatáskörébe".

Ezek szerint tehát a magyar megoldás az, hogy a helyi közügyek fö szabályként önkormányzati feladat- és hatáskörbe kell, hogy tartozzanak. Kivételesen pedig tartozhatnak a közigazgatás másik ágához, az államigazgatáshoz - ez nem közvetett közigazgatás -, de tartozhatnának más szervekhez is. Ez utóbbi alapozhatja meg a közvetett közigazgatást az önkormányzati területen.

\section{Intézményi keretek}

$\mathrm{Az}$ elözőekben tárgyalt jogi keretek lényegében korlátlan lehetöséget teremtenek ahhoz, hogy a közvetett közigazgatást milyen szervezetek valósíthatják meg. Mégis a hatályos jogrendszert tanulmányozva az tünik kézenfekvönek, ha a Ptk-ból kiindulva elsösorban a köztestületeket, a közalapítványokat, a közhasznú társaságokat valamint a költségvetési szerveket soroljuk ebbe a körbe. A lehetséges intézményi kereteket bővíti a nonprofit törvényben rögzített közhasznúsági elem, bár ez utóbbi a feltételek oldaláról közelíti meg a kérdést.

A jogi feltételek alapján azonban nem teljesen kizárt az, hogy az említett körbe nem tartozó szervek vagy természetes személyek is megvalósítsanak közvetett közigazgatást.

Ezek után felmerülhet az a kérdés, hogy a szinte korlátlan jogi lehetőséggel ma hogyan élünk Magyarországon?

A válasz tömören az lehet, hogy a közigazgatási tevékenységek közül a hatósági jogalkalmazó tevékenység tekintetében a közvetett közigazgatás szük körü és problémás, míg a közszolgáltatásokat szervező és biztosító területen nagymértékben elterjedt, és bővülő tendenciát mutat. A jelzett tendencia egyébként megfelel a világon tapasztalható föbb irányoknak, néhány magyar jellegzetességet azonban ki lehet emelni. Az államigazgatási tevékenység szükítésének, és ezzel a központi állami fellépés társadalmi súlyának csökkentésének elvileg két útja van. Az egyik, ha a tevékenység jellege állami marad, de a feladatellátás egy, az ügyfelekhez közelebb 
álló, helyi szintủ állami szervhez, az önkormányzathoz kerül ${ }^{3}$ (decentralizáció). A másik megoldás, ha az államigazgatási szervek által ellátott közigazgatási tevékenységet nem közigazgatási szerv végzi. A széles felelősségkőrủ és elsősorban közszolgáltatásokat szervező helyi önkormányzati rendszerünk miatt az államigazgatástól lényeges decentralizációra már nem kerülhet sor. Vannak azonban olyan központi szinten biztosítható közszolgáltatások, amelyeket nem célszerú helyi szintre telepíteni, az államigazgatási szervezetben való megtartásuk azonban nem szükséges. Ezen a téren az elmúlt években igen nagy lépéseket tettünk az oktatás, a kultúra, a múvészeti igazgatás, a gyermek és ifjúsági ủgyek vagy éppen a sportigazgatảs területén. Az évek óta folyamatosan gyarapodó közalapítványi struktúra jól mutatja azt a tendenciát, hogy fontos, korábban az államigazgatás által ellátott feladatok nem a helyi önkormányzatokhoz kerültek, hanem a civil szférát bevonó közalapitványi és közhasznú társaságokhoz.

Némileg más a helyezet a kőztestületekkel, föként a kamarai típusú szervekkel, amíg ugyanis a közalapítványok és kỏzhasznú társaságok humán és materiális közszolgáltatásokat vettek át az államtól, addig a kamarák - a kötelező tagság feltételéhez kötve - közhatalmi, föként hatósági jogalkalmazó, de kisebb részben szabályozási jogkört is kaptak. Ez a folyamat azonban a kezdetektöl fogva vitatott volt, és joggal. Más országokban ugyanis egy szerves fejlődés eredményeképpen - állami ösztönzés és kényszer nélkül - önkéntesen alakultak ki a kamarák, és az eredményes szakmai érdekképviseleti és szolgáltató tevékenységük alapozta meg azt, hogy az állam közfeladatokat bizzon rájuk. Magyarországon a civil szféra e fontos elemeit nem csupán a jogalkotó hozta létre, de - néhány kivételtől eltekintve - éretlen, kiforratlan állapotukban, a monopolhelyzetukre alapozva terhelte öket a hatósági igazgatási feladatokkal is. Ennek eredményeképpen a kötelező tagság, tagdij, valamint az átadott állami feladatok finanszirozása összefonódott, és bár az igazgatás társadalmasítását jelentő közvetett közigazgatást valósítanak meg, de gyakran szakszerủtlenebbül és kisebb hatékonysággal, mint azt korábban az államigazgatás tette. $\mathrm{Az}$ éretlen viszonyok így éretlen megoldásokhoz vezettek, furcsa azonban a helyzet, mert állami segítség nélkül a kamarák egy része nem tud megerösödni, ha viszont az állami gyámkodás fennmarad, akkor ez összességében nagyobb terhet jelent, mint a hatáskőroök államigazgatásban való megtartása. Ettöl a ponttól kezdve a kérdés immár nem szakmai, hanem politikai jellegủ, és így a megoldás is.

Mindezekre tekintettel, az államigazgatási hatósági tevékenység közvetett közigazgatási útra terelése ma Magyarországon megtorpant, és bár nem a kamarák az egyedüli ilyen jellegü szervek, de más területen sem alakultak ki nagy számban ilyen intézmények.

\section{Az autonóm struktưrák}

Külön kategóriát alkotnak a közvetett közigazgatáson belül az autonóm struktúrák. Amint az a bevezetésből kitünt, itt olyan állami szervekröl van szó, melyek jogállásukat tekintve egyik államhatalmi ághoz sem sorolhatók be egyértelmủen, de mind- 
egyik tevékenységéből végeznek bizonyosokat, így közigazgatást is. Az ilyen típusú szervek létrehozását leginkább olyan fontos, társadalmilag, politikailag kényes területek igazgatása indokolja, amelyek alapvetően befolyásolhatják a hatalommegosztás mechanizmusát. Magyarországon, ilyen szervek közé sorolhatók az Országos Igazságszolgáltatási Tanács, az Országos Rádió és Televizió Testület valamint a Gazdasági Versenyhivatal. A Parlamenthez, Kormányhoz egyaránt kapcsolódó, de azoktól müködésük során tisztes távolságot tartó autonóm struktúrák közé tartozást azonban több központi közigazgatási szerv is megcélozta, így az Állami Pénz- és Tőkepiaci Felügyelet, vagy éppen az Országos Atomenergia Hivatal.

$\mathrm{Az}$ eddigi müködési tapasztalatok igen vegyesek, ezért mindenképpen óvatosan kell eljárni. Magyarország esetében is abból kell kiindulni, hogy az autonóm struktúrák kivételes képzödmények, azok nem alternatívái a tradicionális közigazgatásnak.

Összefoglalva elmondható, hogy a paraállami közigazgatási formák Magyarországon jelen vannak, és a létüket igazoló szükséges mértékben vannak jelen. Kampányszerü és mesterséges úton való terjesztésükre azonban nincs szükség, mert az nem az igazgatás és a civil szféra kapcsolatát erösíti perspektivikusan, hanem a civil szférát vonja állami ellenörzés alá.

\section{Jegyzetek}

${ }^{1}$ Lásd erröl bövebben Állam és jogtudományi enciklopédia (1990) 244-260 oldal, Budapest, Akadémiai Kiadó.

${ }^{2}$ Kihirdette az 1997. évi XV. törvény.

${ }^{3}$ Felfogásom szerint a helyi onkormányzatok részei az állami szerveknek, és nem képeznek ónálló államhatalmi ágat, csak ilyen jellegük van.

\section{Irodalom}

Balázs I. (1990) Közvetett közigazgatás és az autonóm struktúrák a polgári államok közigazgatásában. (kandidátusi értekezés) Budapest, Á.SZ.I.

Balázs I. (1994) A kőzvetett kơzigazgatás és az autonóm struktúrák lehetséges alkalmazási teruletei a magyar közigazgatásban. Alternativ gondolatok a közigazgatásról; dereguláció; a közszolgálat és a nyilvánosság. Magyar Kozigazgatási Intézet Kozigazgatási fuzetek. 13.

Colliard-Timsit (1988) Les autorites administratives independantes. Paris, Edition PUF. 


\section{PARASTATE MODELS IN THE PRESENT HUNGARIAN ADMINISTRATION}

\section{ISTVÁN BALÁZS}

The concept of indirect administration contains all the administrational activities done by non-administrative authorities - established for this pursues in the given legal system. The authorisation can be a general law (e.g. in Hungary) or segmental in laws of certain sectors. The Hungarian legislation has adopted each directions of the local governmental charta (non-obligatory directions too) into the valid law of local governments, therefor regarding to legislation Hungary has one of the most liberate local governmental system in the world. Legal frames create unlimited possibility to the organisational implementation of indirect administration. Parastate administration models are present in Hungary in the necessary extent. However there are no need for their desultory and artificial spread because it doesn't strengthen the relationship of administration and civil sphere, but it takes the civil sphere under state control. 